University at Buffalo School of Law

Digital Commons @ University at Buffalo School of Law

\title{
Razing the Citizen: Economic Inequality, Gender, and Marriage Tax Reform
}

Martha T. McCluskey

University at Buffalo School of Law, mcclusk@buffalo.edu

Follow this and additional works at: https://digitalcommons.law.buffalo.edu/book_sections

Part of the Law and Gender Commons, and the Law and Society Commons

\section{Recommended Citation}

Martha T. McCluskey, Razing the Citizen: Economic Inequality, Gender, and Marriage Tax Reform in Gender Equality: Dimensions of Women's Equal Citizenship 267 (Linda C. McClain \& Joanna L. Grossman, eds., Cambridge University Press 2009)

This material has been published in Gender Equality: Dimensions of Women's Equal Citizenship edited by Linda C. McClain \& Joanna L. Grossman. This version is free to view and download for personal use only. Not for redistribution, re-sale or use in derivative works. (c) Cambridge University Press 2009.

\section{IN COPYRIGHT}

This Book is brought to you for free and open access by the Faculty Scholarship at Digital Commons @ University at Buffalo School of Law. It has been accepted for inclusion in Contributions to Books by an authorized administrator of Digital Commons @ University at Buffalo School of Law. For more information, please contact lawscholar@buffalo.edu. 


\title{
Razing the Citizen: Economic Inequality, Gender, and Marriage Tax Reform
}

\author{
Martha T. McCluskey
}

Social citizenship ideals fall not only outside the bounds of fundamental constitutional rights, but also at the margins of plausible politics in the United States. Citizenship, in the prevailing view, confers the political and civil rights that ensure access to a democratic state and market. That view distinguishes rights to economic equality or socioeconomic security as peripheral, or even antagonistic, to the concerns of democratic government.

Indeed, over the last several decades, leading U.S. intellectuals and policy makers have designed and defended a citizenship vision linked to upward redistribution of economic resources. In this vision, economic inequality and widespread insecurity are necessary and natural to freedom and strength in state and market. Among mainstream leaders of law and politics, the response to this antisocial citizenship has been mostly acquiescence, obliviousness, or resignation, rather than sustained critical analysis or vigorous resistance.

This chapter links the failure of social citizenship ideals in the United States to a broader weakness in citizenship ideals - a weakness that is deeply related to gender ideology and practice. To better advance a vision of social citizenship, U.S. law and politics need a stronger vision, not just of economic equality, but of gender equality and of democracy in general. Feminist scholars have analyzed how ideas about gender help shape the common assumption that the costs of raising and sustaining capable, productive citizens are largely private family responsibilities. But ideas about gender also help to undermine egalitarian economic policy more generally. Gender ideology subtly shapes a vision where civic virtue ironically includes the project of razing citizens: turning democratic citizens into premodern subordinates dependent on private power. I use the example of recent tax policy reforms focused on reducing the so-called marriage penalty to show how problematic ideas of gender, anticitizenship, and economic inequality have become entangled and how these must be reconsidered together to promote a meaningful vision of equal citizenship. 


\section{Social Citizenship in Theory}

\section{Liberal Citizenship, Gender, and Economic Inequality}

Mainstream liberalism tends to frame social citizenship as an oxymoron. As a general political philosophy, liberalism has many richly and widely diverging strands (including both liberal and conservative positions in contemporary U.S. politics). But these strands share a general ideal of a state and society where individuals retain personal freedom, while joining in public self-governance. Many differing versions of liberalism highlight autonomy in the state and market as the characteristic that makes the liberal individual deserving of democratic citizenship, as Martha Albertson Fineman has analyzed.'

Early ideas of the liberal state distinguished the citizen capable of self-determination in market and state from the property, women, children, and servants under others' political and economic custody in the domestic sphere. This traditional liberal framework positions the right to social and economic support as a badge of dependent status squarely opposed to liberal citizenship. Though contemporary strands of liberalism typically embrace a more inclusive vision of citizenship (going beyond white male property owners), the original distinction continues to shape citizenship ideas. In particular, liberal theory continues to presume that the role of the state is to promote and protect individual autonomy, not individual dependence. By defining social citizenship as protection for personal economic security, distinct from political and civil liberty, liberalism sets up a bind in which social citizenship seems to undermine virtuous citizenship. ${ }^{2}$

This link between economic support and gender-based dependent status poses a number of challenges for contemporary advocates of progressive social citizenship. One problem is how to construct rights to social and economic security that include women (and others relegated to a subordinate status) without further confining them to a social sphere apart from and disadvantaged in state and market. ${ }^{3}$ The disproportionately female labor of domestic caretaking tends to be defined in opposition to productive and rational action in state and market. ${ }^{4}$ As a result, women's contributions to state and market are often viewed as so-called social relationships that

1 Martha Albertson Fineman, The Autonomy Myth: A Theory of Dependency (New York: New Press, 2004), at 18-22.

2 See Martha T. McCluskey, "Efficiency and Social Citizenship: Challenging the Neoliberal Attack on the Welfare State," 78 Ind. L. J. 783, 805-06 (2003).

3 For discussions of this problem and its possible solutions, see Mary Anne Case, "How High the Apple Pie? A Few Troubling Questions About Where, Why, and How the Burden of Care for Children Should Be Shifted," 76 Chi-Kent L. Rev. 1753-86 (2001); Linda C. McClain, "Toward a Formative Project of Securing Freedom and Equality," ${ }_{5}$ Cornell L. Rev. 1221, 1251-56 (2000).

4 See, e.g., Katharine Silbaugh, "Turning Labor into Love: Housework and the Law," 91 Nw. U. L. Rev. 1 (1996); Reva Siegel, "The Modernization of Marital Status Law: Adjudicating Wives' Rights to Earnings, 1860-1930," 82 Geo. L. J. 2127, 2131 (1994). 
do not merit political and economic recognition and reward.5 At times, however, government programs have targeted benefits to certain white women (especially those privileged by sexual, marital, and class status) to protect the productive work of "raising citizens." Nonetheless, even when caretaking labor has received public support as essential to political and market well-being, that support typically has been designed as social intervention that operates to limit even the more privileged domestic caretakers' indepęndent political and civil power. ${ }^{7}$ Whether devalued or revered, women's caretaking labor generally has been construed as outside (above or below) the normal operation and normal rights of market and state. ${ }^{8}$

This gendered separation of the social from political and civil spheres stymies social citizenship goals more fundamentally, however. A vision - and division of citizenship that identifies the social sphere with domestic caretaking tends to cast all social citizenship rights in a gendered light. If the social sphere is a place of feminized dependent care distinct from the political and civil spheres of independent citizenship, then social citizenship rights will appear to be protection for dependent status contrary to virtue and power in state and market.

Following such logic, the judicial decisions of the early-twentieth-century Lochner era made social citizenship for independent workers unconstitutional, while carving out exceptions for women, some immigrants, and others whose incapacity for direct citizenship relegated them to paternalistic protection. ${ }^{9}$ Even when white women left home production and caretaking to became factory workers, the law constructed them as quintessential dependents deserving of social protection in lieu of equal citizenship. $^{10}$

Subsequent constitutional doctrine renounced Lochner's rule, opening the door to federal welfare state programs promoting economic equality in the New Deal and, in the 1960 , the Great Society initiatives. However, Lochner's shadow continues to make egalitarian welfare policies appear suspect and stigmatizing, in part because the gendered separation between household dependents and state and market citizens at the heart of Lochner's logic has never been similarly renounced. State economic

5 For discussion and criticism of this presumption, see Fineman, Autonomy Myth, 35-54; see also Linda C. McClain, "Care as a Public Value: Linking Responsibility, Resources and Republicanism," 76 Chi-Kent L. Rev. 1673, 1677-90 (2001).

6 See Alan Pifer and Forrest Chisman, eds., 5oth Anniversary Edition of the Report of the Committee on Economic Security of 1935 and Other Basic Documents Relating to the Development of the Social Security Act 56 (Washington, DC: Project on the Federal Social Role, 1985, 1985).

7 See Mimi Abramovitz, Regulating the Lives of Women: Social Welfare Policy From Colonial Times to the Present 318-19 (Boston: South End Press, 1988).

8 See generally Frances E. Olsen, "The Family and the Market: A Study of Ideology and Legal Reform," 96 Harv. L. Rev. 1497-578 (1983).

9 See Lochner v. New York, 198 U.S. 45, 54-55 (1905) (striking down a New York labor law regulating bakers' hours as an unconstitutional infringement on economic liberty but distinguishing a regulation of miners' hours in part because of the miners' character).

so See Muller v. Oregon, 208 U.S. 412, 418-23 (1908) (upholding a minimum wage law for women and distinguishing Lochner on the ground of women's dependent status). 
protection for workers is still sharply constrained out of concern that economic security will encourage weak, immature, and irresponsible citizens. In part, these concerns have led to programs that privilege groups of workers most identified with market independence, rather than domestic servitude. ${ }^{11}$ Unemployment benefits and old age social security, for example, have been structured to exclude or disadvantage many workers of color and women workers with caretaking responsibilities. But the constraints of Lochner's logic affect even economic security policies identified with masculinized, white, full-time manufacturing workers. For instance, popular media and policy makers have often denounced workers' compensation benefits and international trade protections for U.S. steelworkers, arguing that these discourage the self-reliant character traits that enhance civic and market virtue.

\section{Reviving Social Citizenship}

Advocates of social citizenship have tried to stretch the liberal frame that pits economic support against good citizenship by pushing its boundaries in two directions. First, economic security can be imagined as a precondition, or floor, that will create capacity for meaningful citizenship in state and market. ${ }^{12}$ Second, following T. H. Marshall, economic security can be imagined as a postcondition, or ceiling. ${ }^{13}$ In that second formulation, economic rights are the final step toward perfecting liberal democracy, reached once equal political and civil rights are firmly behind us.

But the gendered liberal framework lashes back against these attempts to stretch autonomous citizenship to include government support for economic well-being. First, as a precondition for political and civil rights, social citizenship reinforces the suspect status of those who claim it so that they appear to be marginal citizens with diminished capacity. When people need a boost up to virtuous citizenship, prevailing politics and theory tend to offer, not material comfort, but the disciplining hand of low-wage (or no-wage) service in market, prison, the military, or traditional marriage.

- For example, in a book that helped shape late-twentieth-century welfare reforms, Charles Murray argued that twentieth-century U.S. social policy failed because public income support programs created incentives for a culture of economic dependence and criminality, especially among nonwhites. ${ }^{24} \mathrm{He}$ focused on what he described as a sharp rise in crime by black men beginning in the 1960s, and he attributed this purported crime wave to insufficient punishment and discipline due to

"See Martha T. McCluskey, "The Politics of Economics in Welfare Reform," in Martha Albertson Fineman and Terence Dougherty, eds., Feminism Confronts Homo Economicus: Gender, Law and Society (Ithaca, NY: Cornell University Press, 2005), at 193, 199.

12 See Cass R. Sunstein, The Second Bill of Rights: FDR's Unfinished Revolution and Why We Need It More Than Ever (New York: Basic Books, 2004), at 185 (giving public support for basic education as an example); Desmond S. King and Jeremy Waldron, "Citizenship, Social Citizenship and the Defence of Welfare Provision," 18 Br. J. Pol. Sci. 415, 426-27 (1988).

${ }_{33}$ See T. H. Marshall, Citizenship and Social Class, and Other Essays (Cambridge: Cambridge University Press, 1950).

14 Charles Murray, Losing Ground: American Social Policy 1950-1980 (New York: Basic Books, 1984). 
expanded welfare and civil rights protections that encouraged female-headed households, alternatives to the discipline of low-waged work, and new policies protecting criminal defendants (especially young black men) from incarceration. Murray advocated "scrapping" public welfare programs to increase economic pressure on those in poverty, especially black Americans and single mothers, so that they would be more likely to participate in wage labor and to make different family choices. ${ }^{15}$ Another prominent think tank writer, George Gilder, similarly used gender and racial ideology to argue that federal income support will not lift families out of poverty. ${ }^{16}$ Gilder argued that economic support from the government will "destroy the key role and authority of the father," thereby fostering a "welfare culture" of laziness and irresponsibility, especially among black Americans, Native Americans, and Latin American immigrants. According to Gilder, effective antipoverty policy must make welfare benefits austere and temporary to encourage "hard work."

The second liberal rationale for social citizenship also invites a backlash against government programs promoting economic equality. If economic security is the icing on the cake after political and civil rights are assured, it will tend to appear to be an unaffordable luxury or unhealthy indulgence that weakens the state and market. By construing state and market freedom as fundamental for justice, and by making socioeconomic well-being separate and supplemental, this theory of social citizenship subtly reinforces the idea that economic inequality is a natural, benign, and often necessary part of the social order. And when state and market seem shaky, this argument for supplemental social citizenship supports the principle that economic resources must go first toward controlling those who threaten the presumed first-order political and civil liberties. The argument for economic rights as the final piece in democratic citizenship therefore risks enhancing a politics that pushes for more policing, more prisons, more military intervention in the public sphere, and more responsibility and sacrifice at home. What may result is a cycle that produces less freedom and security for most: more devastated individuals, homes, and communities, who produce more threats to others' state and market freedom, justifying more diversion of resources away from the separate social projects that would bring broad-based economic security.

For example, in her study of California's prison system, Ruth Wilson Gilmore argues that a punitive "gulag" state replaced a more egalitarian welfare state in the late twentieth century, in response to a political and market crisis marked by California's industrial restructuring and job displacement, agricultural concentration and instability, decreasing federal funds, and rising poverty and immigration. ${ }^{18}$ From

15 Ibid., at 227-28.

${ }^{16}$ George Gilder, "The Coming Welfare Crisis," in Gwendolyn Mink and Rickie Solinger, eds., Welfare: A Documentary History of U.S. Policy and Politics (New York: New York University Press, 2003), at 443-46 (reprinted from 11 Pol'y Rev. 25 [1980]).

17 Ibid., at $443,445-46$.

18 Ruth Wilson Gilmore, Golden Gulag: Prisons, Surplus, Crisis, and Opposition in Globalizing California (Berkeley: University of California Press, 2007), at 40-51, 70-72, 83, 140-55. 
1982 to 2000 , California increased its prison population nearly 500 percent, making the Department of Corrections the largest state agency, consuming about 8 percent of the state's general fund. ${ }^{19}$ Gilmore analyzes this "prison $f \mathrm{x}^{\text {" }}$ as establishing a system of "permanent crisis," in which dehumanization and isolation of "criminals" produces escalating fear, racism, and insecurity in state and market, which in turn diverts public and private funding from local infrastructure, education, social services, and nonprison employment, thereby further exacerbating crime, inequality, and insecurity. ${ }^{20}$

\section{Conservative Challenges to Social Citizenship}

Two prongs of right-wing ideology and advocacy fueled a late-twentieth-century backlash against egalitarian socioeconomic policy in the United States that continues into the current century. The economic branch of right-wing politics, which claims to prioritize market freedom and a minimal state, often seems most directly opposed to social citizenship rights. Its "neoliberal" ideology (drawn from neoclassical economics) holds that an unfettered market, by definition, produces the greatest economic security for the most people, while government "intervention" to promote economic security ends up draining resources and enriching special interests at the expense of the most disadvantaged. This free-market doctrine was given a major boost in the 1970 s by a movement among wealthy business leaders to channel philanthropy into think tanks and scholarship that would promote "free enterprise" and oppose what they often characterized as the "socialist" policies of the New Deal and 1960 , including civil rights laws, welfare programs, and protections for consumers, labor, and the environment. ${ }^{21}$ The John M. Olin Foundation, for example, spent more than $\$ 68$ million to establish the influential "law and economics" school of thought, which challenges the idea that legal rules should be designed to promote the goals of "fairness" or equality.

The social branch of the political Right, in contrast, sometimes seems more conducive to social citizenship goals. Neoconservative ideology sees the state as a legitimate source of moral authority capable of protecting the well-being of families and communities. Neoconservatives have promoted what they claim is a return to moral authority, for example, by promoting domestic policies restricting abortion and sex education and opposing same-sex marriage and by justifying U.S. foreign intervention on grounds of supposedly superior values and culture. ${ }^{23}$ To some extent, this moralistic vision seems to offer support for economic policies designed to restrain individual market greed for the benefit of social solidarity, civic virtue, and human

19 Ibid., at 7-10.

20 See ibid., at 86, 107-13, 177-79.

${ }^{21}$ See Lewis H. Lapham, "Tentacles of Rage: The Republican Propaganda Mill, a Brief History," Harper's, Sept. 2004, at 31-41; John J. Miller, A Gift of Freedom: How the John M. Olin Foundation Changed America (New York: Encounter Books, 2004), 23, 32-37.

22 Miller, A Gift of Freedom, at 62, 71, 81.

23 See Peter Steinfels, The NeoConservatives: The Men Who Are Changing America's Politics (New York: Simon \& Schuster, 1979), at 53-56. 
life and dignity. For example, it might appear that so-called family values advocates could be convinced to focus not only on restricting abortion and gay marriage, but also on increasing public funding for child care and children's health insurance.

Despite the moralistic Right's frequent efforts to regulate community well-being, a closer examination shows how economic and social conservativism work together to undermine social citizenship goals. First, neoliberalism attacks social citizenship by making a gendered, unequal idea of the market the standard for virtuous citizenship. Second, neoconservatism attacks social citizenship by making a gendered, unequal idea of the family the standard for virtuous citizenship.

The economic prong of right-wing politics (neoliberalism) makes policies promoting economic equality appear opposed to freedom and security. The conventional free-market tautology defines equality as coercive intervention in a voluntary market where promotion of individual self-interest naturally maximizes resources for the good of all. The economic Right insists that those who lose out in the inegalitarian market will best achieve economic protection by policies that enhance that market's power to command behavior and to allocate gains. This theory explains that more jobs, and better economic choices, will not come from more rights for workers, more social spending on impoverished children, or more regulation of business to protect consumers, workers, or communities. Instead, the solution is policies that better attract and appease capital owners, who comprise the market's masters, and policies that better discipline the market's workers and consumers. ${ }^{24}$

On the other hand, the social prong of right-wing politics makes egalitarian economic support appear antifamily. This view defines the virtuous, free, and secure family as one in which the promotion of individual sacrifice naturally maximizes resources for the good of society. The moralistic Right insists that those who lose out in the unequal market will best be helped by more fully embracing a hierarchical family model. For them, problems of economic insecurity are solved not by policies promoting equality in government and market, but by policies that remove state and market impediments to family and religious authority to recognize natural inequalities. In this view, true security for the most economically vulnerable comes from attracting and appeasing husbands, or from submission to the discipline of earthly or divine fatherhood, not from government resources. True economic power, according to social conservativism, results not from challenging the masters of market or state, but instead from enhancing the authority of family and religious masters over dependent others. ${ }^{25}$ In this view, if impoverished pregnant women lack the

24 For some examples of this line of reasoning, see generally Daniel Yergin and Joseph Stanislaw, The Commanding Heights: The Battle Between Govermment and the Marketplace That Is Remaking the Modern World (New York: Touchstone, 1998); Thomas L. Friedman, The Lexus and the Olive Tree: Understanding Globalization (New York: Farrar, Straus and Giroux, 1999). For criticisms of this neoliberal challenge to social citizenship, see generally McCluskey, "Efficiency and Social Citizenship."

25 For an example of this kind of argument, from an affiliate of the right-wing Family Research Council, see Allan Carlson, Fractured Generations: Crafting a Family Policy for Twenty-First-Century America (New Brunswick, NJ: Transaction, 2005). For a criticism of family values arguments that dismiss the problem of economic inequality, see Fineman, Autonomy Myth, at 89-94. 
economic and social resources to raise healthy children, then they deserve not more income, public services, or better child care to help them avoid abortion, but stronger controls on their sexual behavior, stronger pressure to put work before family, and more punitive government intervention in their families through the child protection and criminal justice systems. ${ }^{26}$

Together, both intertwining branches of the Right idealize an illusion of citizenship as a privilege linked to independence from the state, grounded in the mythic free market and the mythic self-sufficient family. ${ }^{27}$ And both economic and social strands of the Right draw on gender ideology to legitimate and promote this antisocial citizenship vision. The "nanny state" epithet is used by both the libertarian and moralistic Right to disparage the welfare state and the regulatory state..$^{28}$ The "nanny state" slur expresses the idea that social citizenship is an oxymoron not only because it makes autonomous citizens into coddled dependents, but also because it makes autonomous men into dependent women, children, or servants.

The "nanny state" metaphor not only disparages social citizenship, but also suggests that both economic and social strands of conservativism sow doubt about the value of democratic citizenship itself. This "nanny state" metaphor imagines that the public order depends on a gendered (and classed and raced) status hierarchy: we know government and market have failed if female (or feminized) servants make the rules.

\section{Gendered Challenges to Democratic Citizenship}

The success of the Right's ideas shows that the gendered liberal citizenship framework has problems that go beyond disadvantaging socioeconomic equality in general, and caretaking women in particular. Gender ideology also works to undermine social citizenship ideals by casting doubt on democratic citizenship more deeply and broadly. The prevailing vision of political and civil success not only marginalizes the work of "raising citizens." More insidiously, the prevailing view promotes the gender-infused assumption that razing citizens is fundamental to state and market well-being; that is, recent policy and ideology have subtly (or not) revived and enhanced a vision in which democratic citizenship itself is antagonistic to political and civil virtue.

On the surface, the mainstream commitment to liberalism rejects an older social structure centered on master and servant to embrace a vision of free, selfgoverning citizens. But mainstream liberalism's uneasiness with social citizenship is intertwined with a continued reliance on assumptions of a hierarchical, authoritarian order limited by tradition-bound status.

26 See generally Rickie Solinger, Beggars and Choosers: How the Politics of Choice Shapes Adoption, Abortion and Welfare in the United States (New York: Hill and Wang, 2001).

27 See Fineman, Autonomy Myth, at 31-34.

28 See Martha T. McCluskey, "Thinking With Wolves: Left Legal Theory After the Right's Rise," 54 Buffalo L. Rev. 1191, 1293 (2007). 
Opposition to social citizenship draws on and interconnects with a preliberal and premodern political ideal that models government on the unequal household, where legitimate authority comes from a master's governance of legally dependent family and servants. As Markus Dubber explains, Western traditions of democratic sovereignty not only permitted, but required, a system of inequality in governance. ${ }^{29}$ For the majority, who were household members, rather than household heads, in early European versions of democracy, virtuous governance required submission and sacrifice to a household status hierarchy. The traditional citizen was independent and virtuous to the extent he controlled, protected, and represented others without independent political and market power. That political order was gendered: the status of head of household was linked to masculinity (as well as to race, nationality, sexuality, economic class, and other characteristics). For example, Blackstone's commentaries identified the king as the "father" of his people, explaining that "the individuals of the state, like members of a well-governed family are bound to ... be decent, industrious, and inoffensive in the respective stations. $3^{\circ}$ Dubber argues that this ideal of patriarchal governance was not rejected by the change from monarchy to liberal republican government in the United States, but instead was incorporated within it. ${ }^{1}$ Current controversies over law and government in the United States continue to raise the fundamental question of whether American government should be a democracy of household members, where unequal and dependent status requires most to submit to policing by their autonomous superiors, or whether American government constitutes a democracy of persons equally capable of self-government.

Gender ideology helps perpetuate that older antidemocratic ideal by identifying mastery and servitude with the natural or at least normal and benign characteristics of biological difference within the private family, rather than as a public rejection of democracy. For example, George Lakoff analyzes how an antiliberal view of the family fuels "conservative" opposition to "liberal" efforts to promote equality in the United States. ${ }^{22}$ Lakoff explains that the political Right builds popular support by tapping into a widespread belief that the good family is characterized by sharp gender differentiation, with a father responsible for authority, discipline, and protection over dependent, obedient women and children. 33 In the conservative view, the "strict father" family has become the primary metaphor for the state, creating a frame in which inequality is a virtuous correcting force rewarding successful dominance, while protecting and punishing unsuccessful dependents. Lakoff traces the

29 See Markus Dirk Dubber, The Police Power: Patriarchy and the Foundations of American Government (New York: Columbia University Press, 2005), at 5.

$3^{\circ}$ See ibid., at 49 .

31 See ibid., at 83-93 (describing Jefferson's vision of transforming America from a hierarchical monarchy); see also ibid., at 217 (concluding that Jefferson's effort needs to be revived today because an unexamined patriarchal vision of governance continues to ground American law).

32 See generally George Lakoff, Moral Politics: How Liberals and Conservatives Think (Chicago: University of Chicago Press, and ed. 2002).

33 George Lakoff, Don't Think of an Elephant: Know Your Values and Frame the Debate (White River Jct., VT: Chelsea Green, 2004), at 6-10. 
opposing "liberal" political vision to a sharply contrasting ideal of the "nurturant parent" family, which encourages freedom, gender equality, fairness, negotiation, and caring.

Lakoff explains that for people who identify with the "strict father" family model, government economic support appears immoral and harmful because it interferes with the strict, hierarchical rule that they believe best protects people from a dangerous world. But this conservative "strict father" model leads beyond rejection of social citizenship principles to make equal political and civil rights appear problematic. If virtue comes from using punishment and reward to maintain strong control over dependents, both in the family and in the state and market, then justice and morality will be consistent with substantial authoritarian rule and unequal benefits and burdens in state and society. In this "strict father" model, the discipline of a harsh, unequal market and state appropriately fosters both the coldhearted, uncompromising calculation and the irrational, submissive devotion that establish the morality and power necessary to defend home, business, and nation from ruthless opponents. 34

\section{Advocating Meaningful Equal Citizenship}

Four not-so-easy steps might help proponents of economic equality better challenge the framework that defeats economic equality and gender equity and that undermines the very idea of democratic citizenship as well.

First and foremost, we must reject the separation of political, civil, and social rights. Economic protection is neither the floor below nor the ceiling above civil and political rights, but the core that gives those rights substance and structure. Who has political and civil rights determines who has the power to direct social resources to meet his or her interests, according to his or her ideals and identities. The ideal of formal political and civil rights divorced from substantive power and material benefit is a myth. When political and civil rights are insufficient to command socioeconomic protections, that signifies not just the failure of social citizenship, but the failure of political and civil citizenship as well. The power to share in governing state and market includes the power to define and enact one's economic interests as fundamental virtues, public necessities, and market efficiencies, rather than as redistribution, as luxuries, or as compensation for incapacity. 35

Second, advocates of economic equality should not frame the issue as a debate between security, solidarity, and regulation, on one hand, and risk, individualism, and autonomy, on the other. ${ }^{36}$ The individual autonomy and insecurity claimed by current state and market authorities is rhetoric more than reality. Instead, we should

34 Ibid., at 8-10.

35 See Martha T. McCluskey, "The Illusion of Efficiency in Workers' Compensation 'Reform," 50 Rutgers L. Rev. 657, 918-20 (1998).

${ }^{6}$ See Martha T. McCluskey, "Rhetoric of Risk and the Redistribution of Social Insurance," in Tom Baker and Jonathan Simon, eds., Embracing Risk: The Changing Culture of Insurance and Responsibility (Chicago: University of Chicago Press, 2002), at 146, 164-66. 
reframe the debate as the question of the distribution of security and freedom: who gets protection and who gets risk, and whose interests are advanced and impeded by regulation and social responsibilities. The myth of autonomy covers up a gendered double standard of independence, as Fineman shows. 37 The problem is who deserves substantive citizenship, not whether citizenship encompasses material support.

Third, arguments for economic equality should challenge the opposition to economic equity as a movement against political and civil citizenship, not just against economic citizenship. Both prongs of conservatism promote a restructuring of state, market, and family to encourage control, risk, and coercion for most people as the means of securing power for a few. The illusion of freedom and decentralized power in market and family serves to excuse and support a movement toward increasing state authoritarianism that is eroding liberal citizenship. The rising economic insecurity for the majority in the United States is about a systematic increase in inequality in voting rights, an increase in corruption of democracy by campaign financing and lobbying, and the barriers to representation of diverse viewpoints in the media and in the legislative process - as well as other major flaws in political rights.

Fourth, arguments for economic equality should challenge the prevailing culture of gender difference. Policies of economic security will face popular stigma and political constraint as long as sacrifice, economic vulnerability, and unproductiveness are distinctly feminine virtues, while individual economic mastery over more vulnerable others is the sign of mature masculinity. To break down the ideological separation between political, economic, and social power, it will be necessary to challenge the assumption that this separation reflects a natural, reasonable, or trivial gender division.

\section{Social Citizenship in Public Policy: Marriage Tax Reform}

Taxation is one of the most important policy arenas affecting the questions of economic equality and citizenship in general. Social citizenship rights depend, to a large extent, on determinations of how much economic gain individuals must share with the state, and how that obligation to the state is distributed among citizens. The early-twentieth-century introduction of the income tax, followed by the New Deal payroll tax system for social security, helped support some federal social spending and regulation that led to increased economic equality in the mid-century United States.

Feminists have explored how the twentieth-century United States' steps toward social citizenship were limited by a gendered, racialized vision of economic productivity that privileged formal market work, typically done by white men. But along with work-based income support and protections for workers' rights, midtwentieth-century policy instituted a marriage benefit in the income tax code that (at least implicitly) addressed the economic contributions of some women's informal 
domestic labor. This marriage-based benefit, however, has troubling implications both for women and for social citizenship in general.

\section{Economic Support as Gendered Citizenship}

After 1948, the switch from individual to joint taxation of married couples (combined with favorable marital tax rates) produced a so-called marriage bonus for well-off breadwinner-homemaker married couples..$^{38}$ By treating married taxpayers as a unit, rather than as two separate taxpayers, a relatively high earning breadwinner married to a nonearning or low-earning spouse could split his (very rarely, her ${ }^{39}$ ) market income in half, as if it were really earned by two equal earners. With this 1948 change to joint marital taxation, the couple with a husband earning $\$ 1,00,000$ and a nonearning wife was taxed as if both earned $\$ 50,000$. Because of progressive tax rates, the total tax owed by two individual (unmarried) $\$ 50,000$ earners added together would be lower than the total taxes owed by the combination of one (unmarried) $\$ 100,000$ earner taken together with another taxpayer earning zero.

Progressive tax rates normally reward equality and create incentives to reduce inequality. This 1948 change to marriage-based taxation effectively created an exception to the progressivity rule: it allowed unequal earners, if married, to be rewarded as if they were equal. The as if is important - it was designed to protect high-earning husbands from incentives to.in fact equalize title to family resources. ${ }^{40}$ This system effectively allowed a spouse with significant taxable income to use a nonearning or low-earning spouse as a tax shelter that would substantially reduce the family's tax liability.

Some have claimed that this marriage bonus furthers women's social citizenship because it has acted as support for family caretaking. It even privileges homemaking to some extent, giving greater support to taxpaying units in which one spouse forgoes substantial market income than to single people or married couples without a primary homemaker..$^{4}$

But as feminist critics noted from the beginning, this tax-based system of economic support for caretaking is founded on a vision opposed to women's political and market citizenship. ${ }^{42}$ This tax support for homemaking labor was enacted effectively to impede women's ability to bargain independently for direct compensation for that

$3^{8}$ For a discussion of the 1948 tax law change creating the marriage bonus, see Edward J. McCaffrey, Taxing Women (Chicago: University of Chicago Press, 1997), at 54-57.

39 Data from the pre-1948 system show that in 1918 , only 1.4 percent of wives earned enough to be subject to the income tax individually (exceeding the zero-tax bracket), and by 1939 , less than 7 percent of wives did so. See ibid., at 31 .

$4^{\circ}$ See ibid., at 51-54; see also Carolyn C. Jones, "Split Income and Separate Spheres: Tax Law and Gender Roles in the 1940s," 6 Law and History Rev. 259, 294-96 (1988).

41 See Anne L. Alstott, "Tax Policy and Feminism: Competing Goals and Institutional Choices," 96 Colum. L. Rev. 2001, 2015-18 (1996).

$4^{2}$ See Alice Kessler-Harris, In Pursuit of Equity: Women, Men, and the Quest for Economic Citizenship in 2oth-Century America (New York: Oxford University Press, 2001), at 188-98. 
household labor. The mid-twentieth-century change treating married women not as taxpaying individuals, but as part of a unit consisting of one taxpayer and one spouse, evoked earlier centuries' legal doctrine of coverture, by which a woman largely lost her separate legal identity upon marriage, surrendering independent citizenship for the cover of a husband, who assumed full ownership of the woman's property and income. ${ }^{43}$ Consistent with that tradition, and rejecting the previous half-century of income tax practice, the marriage bonus recognized homemakers not as individuals directly contributing to the state or to the family, but as wives, whose income and obligations are only counted through and claimed by their taxpaying breadwinner spouse.

More materially, this tax support for marital homemaking is not tailored to support traditionally female dependent caretaking. This tax advantage targets marital homemaking regardless of dependents, and separate from other, less generous, dependent caretaking protections. For that reason, the marriage bonus system can be viewed as a policy aimed at supporting "affluent husband care": it recognizes, revives, and subsidizes the traditional coverture duty of wives (or gender-neutral spouses) to forgo market earnings to serve their husbands for no pay. And it affirms the traditional view that the self-governing citizen is one who can command domestic service not as an equal bargainer in a free market, but as a master based on marital status.

\section{Reframing Social Support as Gendered Privilege}

By criticizing this family tax policy as an affluent husband care subsidy, this analysis follows Fineman's call to shift the focus from disadvantage to privilege and to excavate the history of affirmative support for substantive citizenship. ${ }^{44}$ Identifying this privilege and the continuing political interests behind it helps to challenge the conventional wisdom that this marriage bonus is a relic reflecting now-outdated demography, a view that fails to explain why it has not only persisted, but increased, as the married breadwinner-homemaker couple has become less represintative of American families.

In addition, by identifying this tax policy as a problem of unequal power and privilege, rather than of unequal need for support, we can shed light on how to escape the tough trade-offs that confound the question of economic security for family caretakers in the tax system. Many have framed the marriage tax question as a dilemma about whose needs for economic support are stronger: market-working versus homemaking wives; single versus married taxpayers; men versus women; those who satisfy formal definitions of dependency versus those who can prove functional dependency.

Better to promote women's equal social citizenship, this affluent husband care subsidy should not be eliminated, but instead should be extended to support caretaking

43 See Hendrik Hartog, Man and Wife in America: A History (Cambridge, MA: Harvard University Press, 2000), at 115-22.

44 See Fineman's exposition in Chapter 11. 
more equitably for the majority of nonaffluent earners, regardless of marital or family status, and regardless of whether their domestic care comes from market or nonmarket labor. This would involve, first, taxing people as individuals, rather than as a marital unit; second, expanding the progressivity of the tax code to provide more equitable tax relief to support the caretaking needs of low-income and modest-income workers and dependents; and third, structuring tax and other laws formally to recognize and enforce intrafamily exchanges of income and assets for informal family care.

Furthermore, by recognizing the tax system's long-standing privilege for affluent husband care, we may better defend government support for dependent care as continuing a normal and traditional relationship among between state, family, and market - rather than as a supplement to state and market. The husband care subsidy shows that the well-off, two-parent marital family held up as the model of selfsufficiency actually has depended on substantial governmental support. Equalizing and extending that economic support to others will not simply expand "dependency," but will give more people more independent power to negotiate their interests in market and family.

\section{Economic Privilege as Antidemocratic Citizenship}

Recent tax reforms provide an example of the links between opposition to social citizenship and opposition to democratic citizenship. In 2001 and 2003, Congress enacted significant, much publicized reforms to this long-standing marriage tax system. But these reforms did not end the affluent husband care subsidy otherwise known as the marriage bonus. Instead, they ended the so-called marriage penalty for middle income taxpayers. This penalty was actually the result of a 1969 change to the income-splitting rate for married couples: instead of treating married taxpayers as if they were fully equal earners, the 1969 reform treated married taxpayers' income as if it were divided somewhat less equally - as if one spouse earned 70 percent and the other 30 percent, rather than as if each earned 50 percent of the couple's joint income. ${ }^{45}$ This change somewhat reduced the so-called marriage bonus - or affluent husband care subsidy - thereby softening the blow to affluent husbands who divorced their tax-shelter wives.

But this change actually penalized equal-earning married couples because it meant they were taxed at a higher rate than if they were single. Remember that the 1948 marital income splitting system basically altered the normal progressivity of the tax system to reward unequal-earning couples as if they were equal earners: the couple with one $\$ 100,000$ earner and one nonearner was taxed at the lower rate applied to two $\$ 50,000$ earners. Under that 1948 joint marital taxation system, those who really were equal earners did not receive a so-called marriage bonus. Instead, the 1948-1969 scheme left equal-earning married couples with the same standard progressive tax rates as single persons. Under that older system, married couples 
whose earnings were already equal could not gain a tax shelter by attributing a higher earner's income to a lower-income spouse, but they did not lose the normal benefits of the progressive tax rates. The 1969 marriage tax law change had the perverse effect of taking away the normally progressive tax treatment of these equal-earning married couples. Instead, it treated equal-earning marriages as if the earnings were somewhat unequal - creating a marriage penalty for many two-earning couples. After 1969, for example, the husband and wife who each earned $\$ 50,000$ would have been treated as if they earned roughly $\$ 70,000$ and $\$ 30,000$, effectively penalizing them with the steeper tax rate associated with a higher-earning taxpayer.

As dual-earning marriages became a mainstay of the increasingly struggling middle class in the 1970s, this regressive tax penalty became a particular target of criticism. Remember, however, that it was never really a marriage penalty, but always more specifically an equal-earning marriage penalty, and it coexisted with the bonus for higher-income unequal marriages - the affluent husband care subsidy. The series of reforms from 2001 through 2005 largely removed this equal-earning penalty at middle income levels. As a result, those recent reforms might seem to take at least a small step toward more substantive gender equity and economic equity in the tax system, providing a positive example of the possibilities for social citizenship. However, the bigger picture is grimmer.

The so-called marriage penalty was eliminated by expanding the tax bonus for unequal-earning couples - the affluent husband care subsidy - to the higher levels of the $1948-1969$ period. $4^{6}$ The recent reforms replace the 1969 policy of taxing marital income as if it were earned somewhat unequally (split in a $70 / 30$ ratio between spouses) with one taxing marital income as if it were earned on a fully equal basis (a $50 / 50$ split). This means that those married couples with the most unequal spousal division of income can shelter more of the higher-earning spouse's income under the lower-earning spouse's tax rates. For example, a husband earning $\$ 100,000$ will get taxed as a $\$ 50,000$ earner (rather than as a $\$ 70,000$ earner under the 1969 scheme) when married to a wife without taxable income.

By replacing the fiction of a $70 / 30$ marital income split with a fiction of a $50 / 50$ marital income split, the recent reforms claim to alleviate equal earners' marriage penalty because these married couples no longer lose the progressive rates normally available for their individual earnings. Two $\$ 50,000$ earners now will have the same combined taxes, whether married or unmarried, because marriage no longer effectively redistributes marital income to meet the more unequal, and therefore more steeply taxed, $70 / 3$ o division. But these recent reforms still privilege unequal-earning married couples compared to dual-earning married couples and also compared to unmarried taxpayers. By expanding the income-splitting tax shelter so that unequalearning married couples can shift more of the high-earner's income to a lower tax bracket, the recent reforms increase the tax bonus to breadwinners who marry a 
non-earning or low-earning homemaker. An individual earning $\$ 100,000$ with a spouse who specializes in unpaid homemaking, for example, could save over $\$ 6,000$ in annual taxes compared to an unmarried person with the same income (using 2008 tax rates). In contrast, an individual earning \$50,000 who marries a spouse who combines homemaking with $\$ 50,000$ in market earnings will not get any tax savings upon marriage. This tax privilege for unequal-earning marriages is particularly problematic because those couples are typically better off economically compared to dual-earning couples with the same joint formal market income. Dual-earning married couples are likely to work more hours per couple to earn the same market earnings, leaving less time or money for household labor and leisure. 47 Compared to both single taxpayers and dual-earning married couples, married breadwinnerhomemaker couples with comparable income are likely to benefit from substantial informal productive labor and economic security provided by full-time homemakers but not counted as taxable income. By effectively taxing the $\$ 100,000$ breadwinner with a non-earning homemaker spouse as if they were two $\$ 50,000$ earners, the current marital tax system rejects the progressive principle that $\$ 100,000$ is taxed less if it represents the market earnings of two or more workers rather than one. By directing tax support to unequal-eaming married couples, but not to taxpayers filing singly or to dual-breadwinners, the recent current marriage tax system continues to exclude the most burdened middle-class taxpayers from the biggest middle-class tax break.

This inequity shows the power of the right-wing, two-pronged attack on social citizenship, in the tax code and beyond. Protection for unequal family status becomes a political substitute for meaningful economic equality. To address the increasing economic insecurity that has eroded the breadwinner-homemaking family, the Right offers increased privileges for that family. Struggling, dual-earning married couples get relief from penalties based on their formal marital status, without getting substantial support for their actual economic vulnerability. According to social conservative arguments, economic privileges for the breadwinner-homemaker marital family are good for society overall because that is the family that is the model of self-sufficiency and public virtue..$^{8}$ That logic helps justify and normalize the economic vulnerability of dual-earning married couples and single taxpayers as the product of personal choice and character, rather than as the result of exclusion from state and market privileges.

Although the focus on marriage penalty relief suggests a largely moral victory for the social conservatives, a more complete view of the recent tax policy changes shows that the most substantial impact of the reforms went toward advancing the economic prong of the conservative backlash. After all, the real action in the recent

47 See Julie A. Nelson, Feminism, Objectivity and Economics (New York: Routledge, 1996), 104-05.

$4^{8}$ See Wade F. Horn, "The Marriage 'Bonus' Offers Little Tax Relief," Washington Times, April 11, zooo, at $\mathrm{E}_{2}$. 
tax reforms of 2001 and 2003 has been massive tax cuts for the very rich 49 - in the name of shrinking state interference in free market earnings. In dollar amounts, those tax cuts for the rich far outstripped the gains to the middle class from marriage penalty relief. Some have suggested that the marriage reforms acted like a bribe that got enough of the middle class to accept the massive upward redistribution of wealth through the tax system..$^{\circ}$ This would suggest a toned-down vision of social citizenship - limited economic support is possible for the majority if that support is tailored to accommodate a right-wing moral ideal of an unequal family along with a right-wing economic ideal of an unequal market skewed to advantage the very rich. $^{51}$

But a closer look at these tax reforms shows an even worse picture for social citizenship in particular, and for liberal citizenship in general. Marriage remains penalized for many equal-earning couples, especially in lower-income families, who are supposedly the primary targets of pro-marriage policy..$^{2}$ Moreover, the marriage penalty relief these recent reforms offer to the middle class is, to a large extent, temporary and illusory: just as these income tax reforms go into effect, the regular income tax will no longer apply to large portions of the married middle class.53 That is because of an effective shift in the alternative minimum tax, originally designed to close loopholes protecting the rich, but which soon will apply primarily and increasingly to the middle class and not the rich. Indeed, some tax experts suggest that the alternative minimum tax is now perversely aimed at increasing taxes on the middle class to make up the revenue lost from upper-income tax cuts.54 And how does this alternative minimum tax work to increase taxes on the middle class? In part, it does so by eliminating the tax benefits for marriage and for dependent care that would otherwise help the middle-class family. 55

In short, what we get from this picture is not simply a constrained, moralistic, and gendered vision of social citizenship, but a deceptive vision of social citizenship, or more precisely a vision that replaces social citizenship with upper class power and privilege in state and market. In this vision, gender ideology serves to distract and divide the middle class to allow the upward redistribution of wealth.

But these tax reforms also suggest another shift in gendered citizenship. The affluent husband care subsidy of the second half of the twentieth century reflected

49 See Lawrence A. Zelenak, "The Declining Progressivity of the Federal Income Tax," in Paul D. Carrington and Trina Jones, eds., Law and Class in America: Trends Since the Cold War (New York: New York University Press, 2006), at 163-90.

50 See ibid., at 183 .

51 Ezra Klein, "The Rise of the Republicrats," American Prospect, Aug. 13, 2006.

52 See Adam Carasso and Eugene Steuerle, "The Hefty Penalty on Marriage Facing Many Households With Children," 15 Future of Children 157, 159, 163 (2005).

53 See Leonard E. Burman et al., The Expanding Reach of the Individual Alternative Minimum Tax (Washington, DC: Urban Institute and Brookings Institute, 2005), at 4-6.

54 See Zelenak, “Declining Progressivity," at 174.

55 See Jane G. Gravelle, The Individual Alternative Minimum Tax: Interaction With Marriage Penalty Relief and Other Tax Cuts (Washington, DC: Congressional Research Service, 2001), at CRS-7. 
and reinforced an ideal of deserving citizenship represented by the married, white, male, upper-middle-class worker, whose capacity for governance is established by his status as master of the household, entitled to unpaid domestic service. The twentyfirst-century tax system is perhaps taking steps toward replacing this ideal: in place of the affluent husband care subsidy, we have what might be called the "superrich capital care subsidy."

Perhaps the ideal citizen on the horizon is not the married, affluent breadwinner, but the wealthy capital owner, who, as master of the state and market, asserts entitlement to the service and sacrifice of both market workers and family caretakers. In the early twenty-first century, the promise of economic and political power associated with middle-class status in the United States often proves hollow, even as poverty and extreme wealth increase..$^{5}$

Recent tax policy changes track twenty-first-century changes in many other areas of U.S. government policy at the local, national, and international levels, as the burdens and benefits of government and market have shifted to increase protection for a superrich minority at the expense of most others. 57 Income from wage work, government benefits, and retirement is often less secure and more meager..$^{8}$ Rising burdens of housing, health care, and education have squeezed the middle class as well as the poor, and the route toward the American dream typically includes a dual-earning household and a high debt load. But many of these dreams end in bankruptcy, as this path offers little cushion against crisis in work, family, or health. Between 1989 and 1999, the number of women filing for bankruptcy increased over 600 percent, and bankruptcy expert Elizabeth Warren concludes that the data show that raising children is a major economic risk factor for married parents as well as for single women. 59 The chance of falling from the middle class into poverty has increased substantially since the 1960s and 1970s; more than half of American children spend at least a year in poverty before reaching age eighteen, and more than half of all American adults can expect to spend at least a year in poverty between the ages of twenty-five and seventy-five, according to sociologist Mark Rank. ${ }^{60}$ Women work an annual average of 200 hours more than in the mid-1970s; men work an average of 100 hours more; most American families have replaced savings with net debt; bankruptcy (especially in the middle class) has soared; public services - such as education and infrastructure spending - have been starved over several decades in favor of spending on warfare, prisons, and business subsidies; and Americans sacrifice

${ }^{6}$ See Robert Perrucci and Earl Wysong, The New Class Society: Goodbye American Dream? (New York: Rowman and Littlefield, and ed. 2002), at 3-34.

57 See McCluskey, "Rhetoric of Risk."

$5^{8}$ See generally Jacob S. Hacker, The Great Risk Shift: The Assault on American Jobs, Families, Health Care, and Retirement (and How You Can Fight Back) (New York: Oxford University Press, 2006).

59 See Elizabeth Warren and Amelia Warren Tyagi, The Two-Income Trap: Why Middle-Class Mothers and Fathers Are Going Broke (New York: Basic Books, 2003), at 5-6.

6o Hacker, "Great Risk Shift," at 32, citing Mark Robert Rank, One Nation, Underprivileged, Why American Poverty Affects Us All (New York: Oxford University Press, 2004), at 94. 
not only leisure, but sleep, to the growing demands of work and home. ${ }^{61}$ At the same time, lawmakers at the local, national, and international levels typically shape policy in direct response to the demands of their superrich funders, exemplified by the rise in local "corporate welfare" spending and privatization, ${ }^{62}$ the influence of well-funded corporate lobbyists and wealthy campaign donors in national government, ${ }^{\sigma_{3}}$ and international governance (in institutions like the World Trade Organization and the International Monetary Fund) prioritizing protections for multinational corporate profits at the expense of labor, environment, and human rights. ${ }^{64}$ President Barack Obama's election and economic stimulus legislation have spurred hopes that new economic policy will increase support for the middle class. Yet this mobilization for change coincides with a financial crisis in which newly uncovered threats of staggering losses from elite profit-seeking give those elites more power to demand further protection from taxes along with massive increases in government financial support.

Rather than turning wives from servants into citizens, perhaps recent marriage tax policy reflects and reinforces a trend toward turning most citizens (regardless of gender or marital status) into "wives" of capital. Reminiscent of the traditional coverture doctrine giving husbands the right to control women's power to own, earn, and govern, perhaps law and ideology are moving back toward a broader premodern ideal, in which a small group of wealthy property owners and governors are entitled to assert cover over most workers and families, whose power to secure the fruits of their labor is increasingly at the discretion of the rich masters, instead of being a right fundamental to a healthy state, family, and market.

61 See Robert H. Frank, Falling Behind: How Rising Inequality Harms the Middle Class (Berkeley: University of California Press, 2007), at 78-86.

62 See generally Greg LeRoy, The Great American Jobs Scam: Corporate Tax Dodging and the Myth of Job Creation (San Francisco: Berrett-Kochler, 2005).

$6_{3}$ For data on the influence of money in U.S. politics, see Center for Responsive Politics, "OpenSecrets," available at http://www.opensecrets.org/ (accessed Sept. 1, 2008).

64 See, e.g., Jeff Faux, The Global Class War: How America's Bipartisan Elite Lost Our Future - and What It Will Take to Win It Back (Hoboken, NJ: John Wiley, 2006) (reporting on the politics and economics of the North American Free Trade Agreement). 